\title{
ODA 기본법 제정 관련 주요 쟁점과 입법 방향 제언 ${ }^{1)}$
}

\author{
손 혁 상 경희대학교 NGO대학원 교수
}

\section{$\langle$ Summary $\rangle$}

Joining OECD/DAC a year ahead, South Korea's program of Official Development Assistance (ODA) is facing new challenges of reshaping a solid policy framework that would make Korea's ODA more efficient and accountable. In this juncture, an ODA law is likely to be enacted in a near future as shown by the Public Hearings held by the National Assembly in April 2009. Korea, as a rare case, has succeeded to transform itself from a recipient to an emerging donor and enlarges the amount of its ODA recently. However it has to not only set force the rationale, objectives, strategies but, among many other tasks, make aid system coherent and evaluation process transparent. Thus it is now a right time for reshaping Korea's overall ODA policy. Within these contexts, this paper discusses major points at issues of presented bills right after presenting the necessity of enactment of an ODA law. Then it suggests some recommendations to be included in the new ODA law.

\section{I. 들어가며}

한국은 국제원조사회에서 수원국에서 공여국으로 전환된 국가(emerging donor country)라는 독 특한 위치를 차지하고 있다. 특히 미국을 위시한 여러 나라의 대외원조 공여에 힘입어 전후 빈곤 사

1) 본 논문은 2009년 4월 22일 대한민국 국회 외교통상위원회 <ODA법 제정관련 공청회> 발표된 "ODA 기본법안 제정을 위 한 검토의견"을 수정 · 보완하였다. 
회에서 탈피하고, 세계 경제 규모 상위그룹에 진출했다는 점에서 기존 공여국과 달리 개도국으로부 터 특별한 기대를 받고 있다.

그러나 원조규모, 원조의 질과 내용, 집행기구, 평가 분야 등에서 개선해야 할 점이 많다. $\mathrm{OECD}$ 개 발원조위원회(이하 DAC) 회원국의 2008년 GNI 대비 ODA 평균비율이 0.30\%인데 비해 한국은 3 분의 1 수준인 $0.09 \%$ 이다. 원조체계를 살펴보면, 무상원조는 외교통상부, 유상원조는 기획재정부 로 이원화되어 있어 상호협의 및 조정이 미흡함에 따라 수원국에 대한 유무상원조가 상호 유기적으 로 연계됨이 없이 따로 제공됨으로써 원조의 성과가 낮다. 무상원조의 경우 외교통상부뿐 아니라 복지부, 농림수산식품부부, 문광부, 지경부 등 중앙부처와 지방자치단체로 분산화되어 있는데, 통 할 관리 되고 있지 않다. 이 외 ODA 목적에 부합하지 않은 집행이나 투명한 선정절차가 무시되는 등 운용상 많은 문제점이 지적되고 있다. 원조의 질을 보여주는 유무상원조 비율, 원조구속성 비율 등도 선진 공여국 수준에 못 미친다. 중점지원국 선정의 일관성 부재, 수원국지원전략 $(\mathrm{CAS})$ 과 체계 적 평가시스템 미비, 민관협력파트너십 부족 등도 여전히 풀어야 할 과제이다.

한국 정부는 2010년 DAC 가입과 함께 ODA 규모 확대를 대내외에 공언하고 있다. 입법부에서도 국제사회의 원조 규범과 정책에 조응하는 ODA 기본법 제정을 위해 노력하고 있다. 현재 ODA 기본 법은 송민순 의원의〈공적개발원조기본법〉, 진영 의원의〈대외원조기본법〉, 배영식 의원의〈대외 개발협력에 관한 법률〉, 김부겸 의원의〈국제개발협력법〉, 이미경 의원의〈국제개발협력 등에 관 한 기본법>이 각각 발의되어 있다.

이에 현재 발의된 법안에 대한 구체적 검토를 통해 바람직한 ODA 기본법 제정을 위한 제안을 하고 자 한다.

\section{II. 법 제정의 필요성}

현재 ODA 관련법은 〈대외경제협력기금법〉, 〈한국국제협력단법〉, 〈국제금융기구가입조치법〉, 〈정 보격차해소법 등 여러 법률에 분산되어 있다. 이런 이유로 학계를 비롯한 시민사회는 국제원조정 책을 포괄할 수 있는 기본법 제정을 통해 원조정책의 일관성과 효율성을 높여야 할 필요성을 지속 적으로 주장해왔다.

〈표 1〉에서 볼 수 있듯이 22개 DAC 회원국 중 영국을 비롯한 12 개 국가가 ODA 기본법을 제정하 였다. 이 가운데 미국과 스위스 등 7 개국은 헌장(Charter)이나 정책 문서(Policy statement)를 함 
께 채택하고 있다. 독일 등 11 개국은 기본법 제정 없이 정책 문서를 채택하여 ODA 기본정신과 목 적 등 주요 정책기조를 천명하고 있다.

〈표1〉DAC 회원국 ODA 관련 입법 유형

\begin{tabular}{c|c}
\hline \hline 입법 유형 & 해당 국가 \\
\hline \hline ODA 기본법과 정책 문서 & 영국, 스위스, 덴마크, 미국, 스페인, 캐나다, 포르투갈 \\
\hline ODA 기본법 & 벨기에, 룩셈부르크, 이태리, 오스트리아, 그리스 \\
\hline 정책 문서 & $\begin{array}{c}\text { 독일, 핀란드, 일본, 호주, 뉴질랜드, 노르웨이, 스웨덴, } \\
\text { 아일랜드, 프랑스, 네덜란드 }\end{array}$ \\
\hline
\end{tabular}

모든 $\mathrm{DAC}$ 회원국이 $\mathrm{ODA}$ 기본법을 제정하지는 않고 있다. $\mathrm{ODA}$ 정책을 규율하는 법 없이 정책 문 서나 헌장으로 성공적인 원조정책을 펼치는 스웨덴이나 네덜란드와 같은 $\mathrm{DAC}$ 국가들도 있다. 그리 고 한국에서도 지난 노무현 정부 때, 재정경제부를 중심으로 $\mathrm{ODA}$ 헌장을 작성하려는 노력이 있었 다. 입법 대신 정책 문서를 추진한 배경은 $\mathrm{ODA}$ 기본법이 원조정책의 경직화를 가져오고 유연한 정 책 실행에 방해된다는 것이었다. 특히 원조기관의 통합이 현실적으로 어려운 상황에서 실현 불가능 한 입법 노력보다는 일반적인 기본 원칙의 합의가 중요하다는 논리에서 출발했다. 일반적으로 성문 화된 법은 정책 문서보다 의회 승인을 위해 많은 시간과 절차가 필요하다는 점이 큰 한계로 지적된다.

그러나 한국 현실에서는 그 한계보다 입법 효과가 더 막대해 보인다. 한국은 선진 공여국보다 원조 의 역사가 짧다. 원조에 대한 사회적 경험이 역사적으로 축적되지 못하다보니 ODA에 대한 사회적 기반이 약하다. 이런 현실을 고려할 때 성문화된 법이 대외 원조에 대한 국민적 합의와 지지를 확 보하는데 더욱 효과적일 것이다. 또한, 입법은 그 자체로 매우 구체적이며 안정적인 제도적 기반 이 되므로 정권 교체 등 정치적으로 불안정한 상황에서도 안정적인 기조로 ODA 정책을 추진해나갈 수 있는 장점을 가지고 있다. 그러나 무엇보다도 법 제정이 필요하다는 주장에는 입법을 통해 한국 $\mathrm{ODA}$ 의 일관된 정책과 체계를 수립해야 한다는 것이다. 즉 한국 $\mathrm{ODA}$ 의 기본 방향을 대내외에 밝히 고, 일관된 정책기조 하에 그동안 원조 정책의 문제점으로 지적되었던 바를 개선하여 원조 효과성 을 높이기 위해서는 강한 구속력을 가지는 법 제정이 더욱 효과적이라는 것이다.

이러한 배경에서 이미 17 대 국회 회기 중 김부겸 의원과 권영길 의원이 〈대외원조기본법>을 발의 하였고, 우제창 의원의〈국제개발협력기본법〉, 김무성 의원이〈국제개발협력법〉을 발의한 바 있 다. 그러나 안타깝게도 모두 임기만료로 폐기되었다. 18 대 국회에서 집중적으로 발의되는 ODA 기 본법 제안 경위의 논의를 차치해 두더라도, 17 대 국회에 이어 $\mathrm{ODA}$ 기본법에 관한 논의가 국회에서 활발히 진행되는 점은 환영할 만한 일이다. 이제 사회적인 합의 과정을 충실히 하며 한국 ODA가 한 단계 성숙할 수 있도록 법안 제정에 힘을 기울이는 노력이 필요한 때이다. 


\section{III. 법안 내용에 대한 항목별 검토}

\section{1. 법안 명칭}

현재까지 발의된 5개 법안은 '공적개발' ‘대외원조' ‘국제개발협력' ‘대외개발협력'이란 개념을 명 칭에 담고 있다. $\mathrm{DAC}$ 회원국 중 '대외원조'를 법률명에 사용하는 국가는 현재 찾아볼 수 없다. 1961년 미국이 대외원조법〈Foreign Assistance Act〉을 입법했으나, 몇 차례 개정을 거쳐 1979 년에 국제개발협력법〈International Development Cooperation Act〉이 새롭게 발효되었다. ‘공적개발원조’를 법안 명칭에 담고 있는 국가는 캐나다로〈Official Development Assistance Accountability Act>이다. 미국과 캐나다의 법안에서 사용하는 '원조'는 공여국과 수원국간의 직접 적인 수혜관계를 드러내는 개념으로서 '원조'의 수혜성을 강조하는 점과 더불어 $\mathrm{ODA}$ 를 정부 · 지방 자치단체 등의 공적기관 간의 재원 흐름(resource flow)으로 한정하는 성격을 가진다. ODA 관련법 을 가지고 있는 DAC 회원국 중 반 이상이 '개발협력'이란 용어를 법률 명칭에 사용하고 있는데, 이 는 '협력'이란 용어가 수원국과 공여국의 대등한 관계 및 상호의존성을 강조하는 개념으로 이해되 고 있기 때문으로 보인다.

따라서 향후 제정되는 법안에는 민간 기관과 정부의 파트너십을 강조하는 국제사회의 추세를 반영 하고, 시민사회단체, 기업 등 민간기관의 다양한 국제개발협력 참여의 내용을 담을 수 있는 '국제개 발협력'이란 명칭이 들어가는 게 적절해 보인다.

\section{2. 기본정신, 목표 및 원칙}

$\mathrm{OECD} / \mathrm{DAC}$ 는 $\mathrm{ODA}$ 를 'ODA 수혜국으로 $\mathrm{DAC}$ 목록에 기재된 국가/지역에 투입되는 자금을 말하 며 이는 국가, 지방정부, 행정기관을 비롯한 공공기관이 제공한다. 공적개발원조금은 개발도상국의 경제 및 복지 발전을 주목적으로 하여야 한다.’라고 정의하고 있다. 그러나 이는 ODA에 대한 최소 한의 정의일 뿐이다. $\mathrm{DAC}$ 회원국들은 법과 정책 문서를 통해 $\mathrm{ODA}$ 의 목적을 대부분 '전 세계적인 빈곤감소, 세계평화와 안보, 지속가능한 발전’이라고 밝히고 있다. DAC 회원국 중 질적인 면에서 나 양적인 면에서 모두 모범적이라고 평가받는 덴마크는 '개도국 정부 및 공공기관과의 협력을 통 하여 개도국 정부 및 공공기관의 경제성장 촉진을 목적으로 하는 노력을 지원하며, 이를 통해 UN 헌장의 목적과 원칙에 따른 사회적 진보와 정치적 독립을 확보하도록 기여하는 데 목적을 두고 있 다. 또한, 개발협력이 경제 및 기술 분야뿐만 아니라 문화적 협력을 통하여 상호 이해와 연대를 증 진해야 함을 명시 ${ }^{2}$ 하고 있기까지 하다. 이탈리아나 포르투갈 같은 국가는 개도국의 민주주의 원칙

2) 최철영. "대외원조기본법안의 비교법적 검토". 『민주법학』 통권 28호 (2005) pp.181-203 
이나 인권 실현을 표방하고 있기도 하다. 이와 같은 경우를 예외로 한다고 하더라도 $\mathrm{DAC}$ 가입 회원 국들 대부분이 $\mathrm{ODA}$ 의 기본 목적을 개도국의 지속가능한 발전 및 복리 증진에 두고 있다는 것은 명 백하다. ${ }^{3)}$ 일본은 예외적으로 '국제사회의 평화와 개발에 기여함으로써 일본의 번영을 확보한다.'는 다소 동떨어지며 이기적인 목적을 명기하고 있다. 캐나다도 '개도국의 빈곤감소 및 지속가능한 개 발을 통한 자국의 국익신장'을 목표로 밝히고 있다.

원조 목적과 관련하여 '국익’은 매우 중요하며 민감한 문제이다. 국익에 대한 다양한 학술적 논의 가 가능한데, 전통적 현실주의 입장에서는 안보와 경제적 이익 확보를 가장 중요한 국가 이익으로 간주하였다. 그러나 일반적으로 국익 개념에는 크게 생존(physical survival), 자율성(autonomy), 경제적 복리(economic well-being) ${ }^{4)}$ 의 내용이 담겨 있다. 최근에는 집단적 자긍심(collective self-esteem)까지 국익개념에 포함하는 경향이 있다. ${ }^{5)}$ 여기서 집단적 자긍심은 다른 국가들로부터 존경심을 받거나 위상이 높아짐으로서 가지게 되는 국가에 대한 국민들의 좋은 감정을 말한다.

해외원조에 관한 국민여론조사 결과도 이러한 입장을 뒷받침하고 있다. 국제개발협력학회가 2008 년 8월에 실시한 여론조사 결괗에 따르면, 우리나라가 대외원조를 하는 이유는 '과거 원조혜택에 대한 보답'차원이 $30 \%$, '국제사회의 안정과 세계평화 기여' 때문이 $17 \%$, '인도적 의무차원’이 $15 \%$ 순으로 나타났다. 한편, 외교적 국가이익과 경제적 이익을 위한 원조로 이해하는 비율은 $31 \%$ 수준 이다. 한편 대외원조가 국익에 가장 기여하는 분야에 관해서는 '국가이미지 및 국제적 지위 향상' (52.6\%)이 '자원확보, 시장개척 등 경제관계 확대'(14.8\%)의 약 3 배가량 높게 나타났다.

설문조사 결과에서 드러나듯이 우리 국민도 생존, 경제적 복리, 집단적 자긍심과 관련된 국익 차원 에서 대외원조를 지지하고 있음을 알 수 있다. ‘국제사회 안정과 세계평화’라는 보편 가치는 생존의 문제와 연결될 수 있고, 국가위상 제고는 집단적 자긍심의 국익과 연결된다고 볼 수 있다. 과거 원 조수혜에 대한 보답에 관한 응답 역시 간접적이지만 우리 자신에 대한 존중차원으로 해석된다. 따 라서 단기적 경제적 이익 때문에 국익에 기여한다고 대답한 응답자는 전체 응답자 $1 / 6$ 에 미치지 못 하고 있다. 이러한 결과는 예상외로 적은 숫자인데 일부가 가지는 여론에 너무 집착하기보다는 장 기적 차원에서 국민과 대화하여 대외원조가 가져올 수 있는 장기적 국익에 더욱 초점을 맞추는 것 이 좋을 것 같다.

3) 참여연대. 『2008 ODA 정책보고서: ODA 목적과 원조체계』. (참여연대 정책자료집, 2008) pp.7-8

4) Alexander George and Robert Keohane. "The concept of national interests: Uses and Limitations." in George Presidential Decisionmaking in Foreign Policy (Boulder: Westview, 1980) pp.217-238

5) Alexander Wendt. Social Theory of International Politics (Cambridge University Press, 2000) pp.233-8

6) 전승훈, 유철, 김익기, 이주현. 『 개발원조에 대한 대국민 여론조사 및 정부의 국제개발협력정책의 방향 연구』(국제개발 협력학회. 2008) pp,13-4, 41-2. 
현재 무상원조를 규율하고 있는 〈한국국제협력단법〉에 따르면 한국국제협력단(이하 KOICA)의 목 적은 '개발도상국과 우호협력관계 및 상호교류를 증진시키고 이들 국가의 경제 및 사회발전을 지 원하여 국제협력의 증진에 이바지’하는 데 있으며, 유상원조를 규율하는〈대외경제협력기금법>은 $\mathrm{EDCF}$ 의 목적을 '개도국의 산업발전 및 경제안정을 지원하고 이들 국가와의 경제교류를 증진’하는 등 대외경제협력을 촉진하는 데 있다고 밝히고 있다.

김부겸, 배영식안이 제시하는 ‘(경제적)호혜협력’은 대외적으로 우리의 원조가 경제적 이익을 위해 개도국에 제공된다는 부정적인 인식을 줄 가능성이 있다. 단기적인 정치, 경제적 이익의 시각에서 호혜성을 바라보면 인도주의에 기반을 둔 원조이념과 대치될 수 있다. 송민순, 진영안은 모두 '개발 도상국의 세계경제에 대한 참여 확대’를 목표에 포함하고 있는데, $\mathrm{OECD} / \mathrm{DAC}$ 의 정의나 다른 나라 의 입법 사례에 비추어 보았을 때, ODA의 목표로는 부적절해 보인다.

$\mathrm{ODA}$ 기본법에 담길 $\mathrm{ODA}$ 의 기본 철학과 목표는 개도국의 빈곤퇴치, 인도주의와 지속가능개발의 실현, 국제사회의 평화와 번영이라는 인류보편적 가치를 지향하는 것이 바람직하다. ${ }^{7}$ 이 외에도 ‘새천년개발목표(MDGs) 등 국제사회의 개발협력 사업의 목표 이행', ‘대상국의 주인의식 존중 및 대상국과의 파트너십 강화' 등의 사업진행 원칙 등을 반영하는 것도 고려해 볼 수 있다.

\section{3. 원조집행 책임기관}

국제적 차원에서 효율적 원조를 위한 DAC 회원국의 원조체계와 조직 구성의 개선에 관한 국제적 논의가 진행되고 있다. 미국의 경우 USAID의 업무를 국무부 산하에 두고 실시체계의 일원화를 유 지하며 체제 개편의 성과를 거두고 있다. 한국과 원조체계가 가장 유사한 일본의 경우는 1999 년 부터 지속적으로 ODA 증가정책을 채택하고 2003년 ODA 헌장을 개정, 2008년 10월에는 JICA와 $\mathrm{JBIC}$ 을 통합하는 외무성 기구의 개혁을 단행했다. 이러한 일본의 ODA 개혁의 효과는 한국정부의 정책변화에 적절한 시사점을 줄 것이라 평가된다. 캐나다 역시 2002년 기존의 원조정책을 전면 수 정하여 새로운 원조의 기본정책과 방향을 수립하여 기존의 단위 프로젝트를 탈피하고 프로그램 중 심의 사업으로 전면 전환하였다. 한편 독일과 프랑스도 각각 2000년과 1998년에 관련부처 정책을 조정하는 조정기구를 두고 원조수행 기구를 개편하여 국제적 권고에 부응하고 있다. 독일의 경우는 정책조정을 전담하는 경제협력부를 통하여, 프랑스와 일본은 관계부처 장관의 정례적 조정위원회 를 통해 원조정책을 조율하고 있다.

7) 입법단계까지 이르지는 못하였으나 과거 외교통상부가 내부적으로 준비한 법안들에서 표현된 이러한 적극적인 가치 항목 을 참고해 볼만 하다. 2003년에 마련된 국제개발협력법(안)에서는 '보건 · 의료여건 개선 및 성평등 구현에 기여'가 제시되 었고, 2005년에 마련된 대외무상원조기본법(안)에서는 '지속가능한 사회· 경제발전 지원', '민주주의, 인권 및 인도주의 실천, 국제평화와 안보에 기여'가 제시된 바 있다. 
한편, 원조 전담부서를 두는 경우는 호주, 캐나다, 영국과 같이 외교부와 독립적으로 설치된 사례와 네덜란드, 아일랜드, 핀란드, 덴마크 등과 같이 외교부 내 담당인 사례로 나뉘는데, 대체로 경험이 풍부한 $\mathrm{ODA}$ 전문가의 외부인력 강화가 보장된 독립적 전담기구의 활동이 바람직한 것으로 평가되 고 있다. 각국의 사례를 통해 우리는 많은 공여국이 효과적인 원조수행을 위한 단일한 ODA 추진체 계(정책 - 집행기관의 일원화) 또는 통합조정체계(단일 총괄기관 지정)를 운용하고 있다는 것을 알 수 있다.

〈표 2〉DAC회원국 원조집행체계 유형 ${ }^{8}$

\begin{tabular}{c|c}
\hline \hline 외교부 통합형 & 해당 국가 \\
\hline \hline 외교부형 & 덴마크, 핀란드, 노르웨이, 그리스, 아이슬란드, 이탈리아(진행중), 네덜란드 \\
\hline 특별부처형 & 영국(국제개발부) \\
\hline 외교부 산하 원조기관형 & 호주, 일본, 캐나다, 뉴질랜드, 스위스(2개), 미국(다수) \\
\hline 정책일관성을 위한 원조기관 관리형 & 오스트리아, 벨기에, 룩셈부르크, 포르투갈, 스웨덴 \\
\hline \hline 타 부처 분산형 & 해당 국가 \\
\hline \hline 특별부처-다수원조기관 & 독일(경제협력개발부) \\
\hline 유상원조 별개 부처 & 프랑스, 스페인 \\
\hline
\end{tabular}

이러한 국제적 추세에 반해 한국의 ODA는 여전히 무상과 유상으로 이원화되어 관리 운영되고 있 다. 외교통상부가 관리하는 무상원조는 $\mathrm{KOICA}$ 가, 유상원조는 기획재정부 산하 한국수출입은행이 담당한다. 이외 30 여 개 이상의 정부부처와 지방자치단체도 제각각 $\mathrm{ODA}$ 사업에 참여하고 있다. 현 재와 같이 조정기능이 부재한 상태에서 분산된 $\mathrm{ODA}$ 집행체계는 담당부처별 업무조정력과 연계성 을 떨어뜨려 사업의 중복과 예산낭비 등 ODA의 효율성을 저하시키며 일관성 있는 ODA 정책 구현 을 가로막는 요인으로 작용한다. ${ }^{9)}$

기획재정부가 공개한 기관별 $\mathrm{ODA}$ 실적자료에 따르면 외교통상부(KOICA)와 기획재정부(한국수출 입은행) 외에도 24 개의 정부부처와 7 개의 지방자치단체 등 총 31 개 기관이 ODA 사업에 참여하는 것으로 나타났다(2007년 기준, 표3). 이들 정부부처의 예산은 연간 7천7백만 달러로 외교통상부와 기획재정부의 사업에 비해서는 상대적으로 적지만 전체 $\mathrm{ODA}$ 예산의 $11 \%$ 가 넘는 규모이다. 앞으로 2010년 OECD/DAC 가입을 앞두고 원조규모를 늘려가는 상황을 고려한다면 결코 무시할 수 없는 규모이다. 문제는 이들 정부부처와 지자체의 $\mathrm{ODA}$ 사업이 외교통상부, 기획재정부의 유·무상사업 과 업무조정이나 정책협의 구조가 마련되어 있지 않다는 점이다. 따라서 일관된 원조 목적이나 규

8) OECD, 2008. Development Co-operation Report 2007, Paris. 이태주 교수의 '국제개발협력에 관한 국회의 책무와 ODA 기본법' (2008) 재구성

9) 참여연대(2008) pp.5-6 
범에 따라 원조 정책이 추진되고 집행되는 것은 기대하기 어려운 상황이다.

〈표 3〉 기관별 2007년 ODA 지원실적

(순지출 기준, 단위 : 백만 달러)

\begin{tabular}{c|c|c|c}
\hline 기관명 & 양자간 & 다자간 & ODA 합계 (\%) \\
\hline \hline 과학기술부 등 부처(24개) & 43.55 & 30.11 & $73.66(11 \%)$ \\
\hline 서울시 등 지자체(7개) & 3.88 & - & $3.88(0.5 \%)$ \\
\hline 외교통상부/ 한국국제협력단 & 271.36 & 38.72 & $310.08(46.1 \%)$ \\
\hline 재정경제부/ 한국수출입은행 & 143.31 & 140.85 & $284.16(42.3 \%)$ \\
\hline 총계 & 462.1 & 209.68 & $671.78(100 \%)$ \\
\hline
\end{tabular}

자료: ODA기관별 실적에 대해 기획재정부가 정보 공개한 자료를 재구성(2008.5)

2008년 참여연대는 총 54 개 정부부처와 지자체에 ODA 관련 정보공개를 청구하였다. 그 중 ODA 관련 사업을 하지 않고 있다고 밝힌 기관은 24 개이다. 하지만, 기획재정부가 공개한 한국의 기관별 $\mathrm{ODA}$ 실적 자료와 교차 확인한 결과, 이 중 7 개 기관 ${ }^{10}$ 이 $\mathrm{ODA}$ 실적을 보고한 것으로 드러났다. 이 런 차이가 발생한 이유는 여러 가지로 짚을 수 있겠지만, 결과적으로 각 기관의 ODA 사업이 매우 허술하게 관리되고 있음을 확인할 수 있다. 사업실적의 수치가 일치하지 않는 기관도 상당수였다. 이런 현실은 해당 기관의 책임을 묻기에 앞서 이를 관리하고 통할하지 못하는 현행 집행구조의 문 제라고 할 수 있다. ${ }^{11)}$

송민순안의 경우 외교통상부 장관과 $\mathrm{KOICA}$ 를 중심으로 하는 단일한 원조집행체계를 제시하고 있 어 통합된 원조개념과 일관된 방향을 보이고 있다. 반면, 진영, 김부겸, 이미경안은 현재의 시행체 계와 유사하게 무상원조는 외교통상부 장관 책임하에 $\mathrm{KOICA}$ 등에 위탁이 가능하도록 규정하고, 유상원조는 기획재정부 장관의 책임하에 수출입은행 등에 위탁이 가능하도록 규정하고 있다. 또한, 다자기구 지원을 국제적 흐름에 맞게 유상(국제기구출자/차관)과 무상(국제기구분담금/출연)으로 구분하여 무상 다자원조는 외교부가, 유상 다자원조는 기획재정부가 총괄하도록 하고 있다. 그러나 배영식안은 유무상원조의 이원화를 인정하면서, 다자원조 중 국제개발금융기구는 기재부가 총괄하 고 유엔기구 등 여타 국제기구는 외교부가 총괄하도록 한다. 김부겸, 이미경안의 경우, 지방자치단 체가 시행하는 원조는 행정안전부장관이 총괄하도록 명시하고 있다.

현 정부행정체계 개혁의 어려움을 고려하지 않는다면 외교부 산하에 원조를 총괄하는 '(가칭)대외 원조청'을 두거나 외교통상부 중심의 집행체계 수립이 원조집행체계의 일관성을 확보하는 차원에

10) 관세청, 국가보훈처, 국가청렴위원회, 국세청, 식품의약품안전청, 전라남도, 통계청

11) 참여연대. (2008). p.11 
서 바람직해 보인다. 그러나 이러한 방향을 제시한 송민순안은 현재의 분산화된 원조체계를 일원화 하는 과정에서 각 부처 간의 조정문제, 조직의 통합 방안, 전문성 확보 방안 등에 대한 고려를 반영 하지 않아 법안의 실효성에 대해서 의문을 가지게 한다. 또한, $\mathrm{ODA}$ 기본전략도 외교통상부 장관이 최종적으로 결정하는 것으로 규정하여 원조위원회의 역할을 미미하게 하는 한편, 외교통상부장관 의 권한에 대한 통제를 어렵게 하고 있다.

나머지 네 개 법안은 유 - 무상원조 집행기관의 이원적 총괄구조를 지지하고 있다. 이 법안들은 현 재 한국 $\mathrm{ODA}$ 집행에서 가장 큰 문제로 지적되고 있는 유무상 간, 다양한 원조집행기관 간의 정책 일관성 문제를 해결하지 못할 뿐만 아니라 현 상황을 제도적으로 승인해서 고착화될 위험이 크다. 따라서 '대외원조청'의 설립이 현재 불가능할 경우에는 무상원조는 외교부가, 유상원조는 기재부가 총괄하는 것을 한시적으로 허용한다는 조항이 반드시 들어가야 한다. 이와 함께 공적개발원조를 담 당할 독립부처가 생길 때까지 범정부 차원에서 유무상원조를 일관성 있게 조정할 수 있는 국무총리 산하 ‘국제개발협력위원회’의 역할과 권한 강화가 우선되어야 한다.

\section{4. 정책조정기구: 국제개발협력위원회 구성}

$\mathrm{OECD/DAC는} \mathrm{'08년} \mathrm{우리나라} \mathrm{원조에} \mathrm{관한} \mathrm{특별검토(special} \mathrm{review)에서} \mathrm{우리} \mathrm{원조의} \mathrm{분산화} \mathrm{-} \mathrm{파}$ 편화 문제의 심각성을 지적하며 개발협력의 목적 · 정책 · 전략을 총괄하는 단일한 조직 구성을 권 고하였다. 정부에서도 분산된 집행체계를 극복하고 국가 차원의 기획조정이 필요하다는 배경에서 국제개발협력위원회를 설치하였다. 국제개발협력위원회는 2005년 11월 정부의 대외원조 개선 종 합 대책>에 따라 유 - 무상원조 정책을 통합해 총괄 심의하기 위한 목적과 중장기 국제개발협력 추 진계획 심의와 국제개발협력 추진전략 수립, $\mathrm{ODA}$ 실적 평가를 담당하기 위한 취지에서 국무총리실 산하에 구성되었다. 각 부처를 총괄 조정하기 위해서 국무총리를 위원장으로 두고 각 정부부처 장 관과 $\mathrm{KOICA}$ 이사장, 한국수출입은행장, 민간위원 등 24명으로 위원회를 구성하고 실무 지원을 위 해 산하에 실무위원회를 두었는데, 이로써 부분적이나마 분산된 한국의 ODA 집행체계를 보완하고 총괄적인 정책수립과 업무조율을 할 수 있는 제도적 틀이 마련되었다는 기대를 받았다.

하지만, 그동안 국제개발협력위원회의 운영을 살펴보면 기대에 부응하지 못하고 있다. 출범 후 지 금까지 단지 몇 차례 회의가 소집되었을 뿐이다. 사정이 이렇다 보니 매년도 국제개발협력사업 계 획안의 수립과 심의, 실적평가, 중장기 국제개발협력 추진전략은 제대로 수행되지 못한 채 제자리 를 맴돌고 있다. 게다가 이명박 정부가 들어서고 나서는 국제개발협력위원회의 폐지가 거론되는 등 그나마 활동조차 지연되고 있다. 실질적인 심의 · 조정기능을 뒷받침할 수 있는 인력과 예산이 배정되 어 있지 않아 적극적인 활동을 하기에는 현실적으로 불가능한 상황인 것이다. 
발의된 5개 법안 모두 공적개발원조에 관한 주요 사항을 심의 · 조정하는 위원회 설치를 제안하고 있다. 이미경안은 더 나아가 이 위원회에 의결권한까지 부여하고 있다. 먼저 송민순안을 살펴보면, 심의 조정 위원회의 소속이 불분명할 뿐만 아니라, 외교통상부 장관에게 ODA 정책결정 기능을 집 중시켜 위원회의 역할을 유명무실하게 하고 있다. 진영의원 등 나머지 법안은 국무총리 산하의 원 조위원회가 ODA 기본계획 등을 수립하도록 하고 있어 송민순안과 대비된다.

위원회의 민간 위원 참여 문제를 볼 때, 진영안은 원조위원회에 대한 민간전문가의 참여를 전혀 고 려하지 않고 있다. 다른 4 개 법안이 다소 차이가 있지만, 민간전문가의 원조위원회 참여를 보장하 는 방향을 취하고 있는데 반해 진영안은 상당히 후퇴한 태도로 보인다. 원조위원회의 민간위원 참 여는 $\mathrm{ODA}$ 기본법 제정에 있어서 핵심적 요소 중 하나이다. 시민사회에서 위원회가 심의 · 조정기 구의 역할을 제대로 수행하기 위해서 과반수의 민간이 참여해야 한다는 의견을 제시하고 있는 상황 에서 진영안이 이를 간과한 것은 심각한 문제이다.

정부부처 간의 정책조정 등이 필요한 $\mathrm{ODA}$ 관련 업무의 특성상 원조위원회는 대통령 직속 또는 국 무총리 산하에 두는 것이 바람직할 것으로 보인다. 나아가 원조위원회에 주요 계획의 심의 및 최종 결정권한을 포함한 실질적인 $\mathrm{ODA}$ 정책결정의 위상을 부여하는 것이 필요해 보인다. 또한, 민간위 원들의 참여가 보장되어야 할 것이다. 이를 통해 $\mathrm{ODA}$ 정책에 대한 신뢰성 및 투명성 제고가 담보 될 수 있을 것이기 때문이다.

원조시행계획 책임기관의 쟁점을 살펴보면, 외교부는 시행계획은 개별기관이 수립하고 책임기관이 이를 총괄 - 조정해야 한다는 입장인데 반해, 기재부는 시행계획은 개별기관이 수립하고 총괄기관 은 이를 단순 취합(종합)하여 원조위원회가 심의 · 조정해야 한다는 입장이다. 분산화 된 한국의 원 조체계 하에서 최소한 무상원조 분야에서만이라도 외교부가 총괄해야 한다는 입장은 수긍할 수 있 으나, 원조위원회가 중장기 기본계획만 심의하고 시행계획을 심의하지 않을 경우 현재 유무상 간의 정책일관성 문제를 여전히 풀어갈 수 없다고 본다. 따라서 위원회가 유무상원조 시행계획 간의 일 관성을 확보하고 중복을 피할 수 있는 제도적 장치가 반드시 필요하다고 본다.

그리고 위원회의 간사는 외교통상부 장관이 담당하는 것이 바람직하다. 외교통상부장관이 간사위 원을 맡고, 위원회 토의안건에 관하여 사전 협의 · 조정하는 실무위원회를 관장하도록 함으로써 30 여 개 정부부처에 분산된 원조체계를 원활하게 조정하고 통합하도록 해야 한다. 


\section{5. 원조 대상국가}

배영식안을 제외한 나머지 4개 법안 모두 개발도상국의 범위를 $\mathrm{OECD} / \mathrm{DAC}$ 가 정한 기준에 따르도 록 하고 있어 개발도상국 선정 · 과정상의 자의를 배제할 수 있을 것으로 평가된다. 배 의원안의 경 우 대외원조위원회 심의를 거쳐 국무총리가 개발도상국범위를 정할 수 있도록 했는데, 이는 정치적 목적으로 지원 대상을 부적절하게 확대할 수 있는 부작용의 가능성 있다.

송민순안과 진영안은 나아가 개발도상국 중에서 다시 협력대상국과 중점협력대상국을 정하여 원조 범위와 우선순위를 달리할 수 있도록 하고 있다. 협력대상국에 대해서는 GNP, 경제 및 사회발전단 계, 산업구조를 고려하게 되어 있어 최소한의 기준을 마련하였다. 중점협력대상국과 관련하여서는 송민순안이 UN 최빈국 중심으로 선정기준을 제시하고 있음에 반해 진영안은 일정한 기준 없이 각 책임기관이 이를 선정하도록 하여 선정 - 과정상의 자의가 개입될 여지를 넓게 두고 있다. 정치적 고려나 부적절한 원조대상 선정 등의 폐해를 방지하기 위해서는 ODA 기본법이 추구하는 원칙을 반 영한 대상 선정의 기준을 구체화하는 것이 바람직해 보인다. 유무상 책임기관에서 각각 다른 중점 협력대상국을 선정하지 않고, 국제개발협력위원회에서 유무상 통합 중점협력대상국과 국가별 중기 지원전략을 수립하여 정책일관성을 유지하는 것이 필요하다.

\section{6. 개발경험의 전수}

‘한국형 대외원조모델’과 연계되어 있는 개발경험 전수 사업에 대해 시민사회 전문가 그룹은 공개 적으로 명시되지 않는 것이 적절하다는 의견을 권고해 왔다. 왜냐하면 '개발경험과 지식의 전수’를 $\mathrm{ODA}$ 의 내용으로 전면에 내세울 경우, 한국 ODA가 현지의 특수성을 심도 있게 고려하지 않고 다 른 사업 분야보다 우리의 성공사례를 홍보하는데 치중해서 $\mathrm{ODA}$ 의 본질적 가치를 희석시킬 수 있기 때문이다. 그뿐 아니라, 이미 대상국의 경제 - 사회 발전이 $\mathrm{ODA}$ 의 목표로 제시된 마당에 굳이 이를 반복할 필요도 없다.

개발경험 공유사업은 외교부 산하 $\mathrm{KOICA}$ 가 무상 기술협력 형태로 시행하고 있으며, 기재부 등 타 부처에서도 별도 프로그램을 시행하고 있다. 특히 재정부는 2004년 이후 $\mathrm{KDI}$ 를 통해 경제개발 분 야에 초점을 둔 〈경제개발경험 공유사업 $(\mathrm{KSP})$ 〉을 별도 진행하고 있다. 2008년 1월 국제개발협력 위원회에서 부처 · 기관 간 통합된 '개발경험 공유 활성화 기본계획(안)'을 수립하였다. 그러나 신정 부 출범 등으로 인해 현재 추진실적은 미비한 상태이다.

개발경험 전수 사업은 무상원조사업에서 대표적으로 중복 및 혼선이 야기되는 사례이다. 사업의 
목적, 분야 및 대상국이 대부분 $\mathrm{KOICA}$ 무상원조사업과 유사하고 무상원조의 국별지원전략 적용 을 받지 않기 때문에 특정 수원국에 대한 중복지원이 발생하고 있다. 예를 들면 인도네시아의 경우 $\mathrm{KOICA}$ 의 기상예보, 국제통상, 관세행정지원 사업이 $\mathrm{KSP}$ 의 기상 조기경보시스템, 수출, 관세행정 개선 사업과 중복되어 시행되었다. 이외에 베트남, 우즈베키스탄, 캄보디아, 알제리에서도 중복사 업의 문제점이 드러났다.

송민순, 진영안은 개발경험 전수 사업은 무상원조 총괄기관이 총괄하는 조항을 담고 있으나, 배영 식안은 기획재정부가 전문관리기관으로 한국개발연구원을 지정할 수 있다고 정하고 있다.

개발경험 공유사업은 경제분야 뿐만 아니라 농촌 - 도시개발, 과학기술, 인력개발 등 개도국 국가 발전에 필요한 광범위한 분야를 포괄하고 있기 때문에 관련 부처 공동참여가 바람직하다. 따라서 협의기구를 구성하여 무상원조 총괄기관의 조정권한을 부여할 수 있다. 다만, 기재부의 경우 기존 ‘KSP 사업’의 성과 및 비교우위를 바탕으로 경제개발전략, 재정, 금융 등 거시 경제분야를 분담해 서 담당하는 것이 바람직하다. 그런데 이러한 업무분장은 시행세칙에서 다루는 것이 더 적절할 것 이다.

\section{7. 평가}

평가는 5 개 법안 모두 구체적인 내용이 미흡해 예전에 제출된 법안에 비하여 가장 크게 퇴보한 부 분으로 평가된다. 예산의 적정한 사용과 관련하여 평가의 적정성 확보는 $\mathrm{ODA}$ 기본법이 규율해야 할 가장 핵심적인 문제로, 평가의 구체적인 기준과 절차에 대한 규정이 필요하다.

송민순안은 외교통상부 장관, 배영식안은 기획재정부 장관이 각각 주관하여 원조위원회에 보고하 도록 하고 있다. 이에 반해 진영, 김부겸, 이미경안은 국무총리가 평가를 주관하며 대통령령으로 시 행세칙을 정하도록 하고 있다. 시행세칙이 마련되는 추이를 지켜봐야 하겠지만 1991년 DAC이 채 택한 투명하고 공정한 원조평가의 원칙을 이행하기 위해서는 외부전문가가 포함된 평가위원회가 독립적으로 운영되는 것이 바람직하다. ${ }^{12)}$ 기존의 평가나 발의된 법안의 평가방식을 보면 모두 내부 평가방식으로 외부평가보다 독립성과 공정성을 유지하기가 어렵다. 따라서 원조위원회 산하에 독 립적인 평가위원회를 설치하여 사업결과에 관한 평가를 시행하고, 평가결과가 체계적인 피드백을 거쳐 중장기정책 및 연도별 시행계획에 반영될 수 있도록 해야 한다.

12) 장현식,아더 엠. 펠,마이클 레어드. 2007. 『OECD/DAC 회원국의 개발협력 관리체계 비교』정책연구 2007-6-141. KOICA. pp.177-89 


\section{8. 국회 보고 의무}

공적개발원조는 정부 예산 즉, 국민이 낸 세금으로 집행된다. 이는 국민이 공적개발원조가 어떻게 쓰이는지 알 권리가 있고, 반대로 정부는 국민에게 투명하게 공개할 의무가 있다. 견제와 균형의 원 리에 입각해서 해당 장관에게 원조의 중장기 ${ }^{13)}$ 계획과 기본 전략을 국회에 보고하도록 하여 ODA에 대한 국회의 평가 및 감시 기능을 제도화해야 한다. 한편, 국회는 이를 국민에게 성실하게 공개해서 시민사회에서 $\mathrm{ODA}$ 집행에 대한 감시와 공론화가 가능하도록 해야 한다.

특히 기재부는 〈국제금융 가입조치에 관한 법률〉에 의거해서 2001년 이후 작년까지 58억 달러 이 상(올해 계획 포함 시 66억 달러 이상)을 국회의 동의 없이 정부예산이 아닌 한은의 외화보유액 등 을 이용하여 국제금융기구에 출연 · 출자하였다. 이와 관련해서 송민순, 이미경안은 ODA 재원은 원칙적으로 정부예산으로 사용할 것을 규정하고 있다. 헌법 제 58 조는 '....예산외에 국가의 부담이 될 계약을 체결하려 할 때 정부는 미리 국회의 의결을 얻어야 한다.'라고 명시하고 있다. 헌법 정신 에 맞게〈국제금융 가입조치에 관한 법률〉 개정이 필요함과 동시에 국가에 중요한 재정적 부담을 지우는 출연 · 출자는 원칙적으로 정부예산으로 하되, 정부예산으로 하는 것이 힘들 경우에는 반드시 국회의 동의를 받도록 ODA 기본법에 관련조항 반영이 필요하다.

\section{9. 민간해외원조단체에 대한 지원}

1990년대 이후, 민간영역의 국제개발협력이 활발하게 이루어져 오고 있으나 민간해외원조단체들 을 통한 $\mathrm{ODA}$ 사용은 $\mathrm{ODA}$ 전체 규모의 $1 \%$ 에 불과하다. 발의된 5 개 법안 모두 민간해외원조단체에 대한 지원을 규정하고 있으나, 지원하는 대상과 규모에 대해서 자의적으로 결정할 수 있는 여지를 두고 있다. $\mathrm{OECD} / \mathrm{DAC}$ 국가의 평균인 전체 $\mathrm{ODA}$ 예산의 $5 \%$ 정도를 민간단체에 지원하는 것과 같 은 기준을 명시해 둘 필요가 있다.

\section{0. 재외공관의 역할}

송민순, 진영, 이미경안은 법안에서 재외공간의 역할을 규정하고 있다. 원조사업을 발굴, 계획, 이 행, 모니터링 과정에서 현지 사정을 제일 잘 아는 재외공관의 적극적인 참여가 요구된다. 기본계획, 시행계획, 국별원조전략을 수립할 때 재외공관의 검토의견을 참고하고, 재외공관의 모니터링 결과 가 유무상 원조책임기관에 전달되어 정책결정과 실행에 반영되어야 한다. 이를 위해 진영안의 21

13) 김혜경. 2008. "한국 ODA 선진화를 위한 제언: ODA 기본법 제정을 중심으로" 『한국 ODA 선진화를 위한 토론회: ODA 기본법제정을 중심으로』송민순의원실, 국회 한국외교와 동북아 평화연구회. 
조(재외공관의 역할)는 존치되는 것이 필요하다. 다만, 재외공관의 자의적인 권한 행사를 막기 위한 권한의 한계를 분명히 하는 것도 고려되어야 한다.

〈표 4〉 제안 요약

\begin{tabular}{|c|c|}
\hline 조항 & 제안 내용 \\
\hline 1. 법안 명칭 & 국제개발협력법 \\
\hline 2. 기본정신, 목표 및 원칙 & 개도국의 빈곤퇴치, 인도주의와 지속가능개발실현, 국제사회 평화와 번영 \\
\hline 3. 원조집행 책임기관 & $\begin{array}{l}\text { 1.(가칭)대외원조청 신설 } \\
\text { 2. 무상 외교부, 유상 기재부 총괄의 한시적 시행을 명시 }\end{array}$ \\
\hline 4. 정책조정기구 & $\begin{array}{l}\text { 국제개발협력위원회 } \\
\text { - 국무총리(위원장) } \\
\text { - 외교부장관(간사) }\end{array}$ \\
\hline 5. 원조 대상국가 & $\begin{array}{l}\text { 국제개발협력위원회 주관 } \\
\text { 유무상 통합 중점협력대상국 선정 }\end{array}$ \\
\hline 6. 개발경험의 전수 & $\begin{array}{l}\text { 외교부: 무상원조 사업 총괄 } \\
\text { 기재부: 거시경제분야 유상원조 총괄 }\end{array}$ \\
\hline 7. 평가 & 국제개발협력위원회 소속 평가위원회 구성 \\
\hline 8. 국회 보고 의무 & $\begin{array}{l}\text { 원조사업 국회보고 의무화 } \\
\text { 정부예산 이외의 출연 · 출자는 국회동의 의무 }\end{array}$ \\
\hline 9. 민간해외원조단체에 대한 지원 & 전체 ODA규모의 $5 \%$ 명시 \\
\hline 10. 재외공관의 역할 & 재외공관의 역할 강화 \\
\hline
\end{tabular}

\section{IV. 마치며}

현재 발의된 5 개의 법안은 아직 법안심사소위에서 논의되고 있는 단계이지만, 이미 크고 작은 장 에서 공론이 형성되어 가고 있다. 본 글에서는 입법기관을 통해 제출된 법안 항목 검토를 통해 $\mathrm{ODA}$ 기본법에 담길 내용을 제안하였으나, 전제해야 할 몇 가지 관점이 있다. 첫째는 입법 내용에 $\mathrm{OECD} / \mathrm{DAC}$ 으로 상징되는 선진공여국의 원조규범을 비롯해 국제적 차원에서 축적된 $\mathrm{ODA}$ 관련 국 제규범의 성과가 반영되어야 한다. 한국 정부는 그동안 신흥공여국에서 선진공여국으로 발돋움하 겠다는 목표를 공공연히 천명해왔다. 선진공여사회에 진입하기 위해서는 원조 규모, 원조의 질, 원 조 효과성 등 다양한 차원에서 제기되는 국제적 권고를 무시해서는 안 될 것이며, 원조 커뮤니티에 서 보편적으로 자리 잡은 국제규범들이 입법 과정에서 반영되어야 할 것이다. 다음으로는 입법 목 표나 취지의 맥락이 단순하지 않다는 것을 고려해야 한다. 현재 ODA 기본법 제정을 요구하는 흐름 은 크게 $\mathrm{ODA}$ 와 관련하여, 강한 사회적 규범이 필요하다는 차원에서 입법을 요구하는 견해, 입법을 
통해 후진적인 $\mathrm{ODA}$ 집행체제를 개선하자는 견해, $\mathrm{ODA}$ 집행기관의 특수한 이해를 대변하기 위해 입법을 제안하는 견해 등 몇 가지가 있다. 입법 과정을 통해 다양한 이해관계자들의 입장이 수면위 로 부상하며 적극적인 상호 작용이 전개될 것으로 기대되는데, 다양한 입장들이 합의를 이루기 위 해 가장 중요한 것은 현 시점에서 입법 목표를 무엇으로 설정하느냐가 될 것이다. 아직 입법이 현 실화되기까지 많은 시간이 필요하겠지만, 최소한 $\mathrm{ODA}$ 관련 정책을 일관되게 규율할 수 있는 분명 한 원조 목적과 분산화된 $\mathrm{ODA}$ 집행체계의 문제점을 개선할 수 있는 제도적 기반을 갖추는 내용은 담겨야 할 것이다. 마지막으로 입법과정에 시민사회의 참여가 반드시 이루어져야 한다. 최근 국제 빈곤퇴치 NGO 등 시민사회를 통한 원조가 주요한 원조 채널로 부상하고 있다. 이런 현실을 고려할 때 $\mathrm{NGO}$, 기업 등 민간기관이 적극적으로 $\mathrm{ODA}$ 기본법 제정 과정에 관심을 가질 수 있고 참여할 수 있도록 다양한 조치를 취해야 한다. 법 제정이 ‘그들만의 리그’가 되지 않도록 말이다. 법을 만드는 과정은 $\mathrm{ODA}$ 에 대한 국민적 관심을 환기하고 제고할 수 있는 기회가 될 수 있다. 국민은 ODA 재원 인 세금을 내는 납세자로서, $\mathrm{ODA}$ 의 매우 중요한 이해관계자이다. 시민의 정보 접근권을 강화하고 입법 과정에 참여할 기회를 제공하여 역동적인 입법 과정을 만들어 나가는 것도 중요하다는 인식이 필요하다. 


\section{참고문헌}

\section{1. 국내문헌}

권율 외. 2006. 『우리나라 대외원조정책의 선진화 방안: 국제개발협력 패러다임의 변 화와 한국ODA의 개혁과제』 연구보고서 06-03. 서울: 대외경제정책연구원.

김부겸. 2008. 「국제개발협력법안」,2008년 11월 3일 제안.

김혜경. 2008. “한국 ODA 선진화를 위한 제언: ODA기본법 제정을 중심으로 “『한국 $\mathrm{ODA}$ 선진화를 위한 토론회: $\mathrm{ODA}$ 기본법제정을 중심으로』. 송민순의원실, 국 회 한국외교와 동북아 평화연구회.

배영식. 2008.「대외개발협력에 관한 법률안」, 2008년 10월 31일 제안.

송민순. 2008.「공적개발원조기본법안」,2008년 7월 4일 제안.

이미경. 2008. 「국제개발협력등에 관한 기본법안」, 2008년 3월 20일 제안.

이태주. 2008. “국제개발협력에 관한 국회의 책무와 ODA기본법” 『한국 ODA 선진화 를 위한 토론회: ODA 기본법제정을 중심으로』. 송민순의원실, 국회 한국외교 와 동북아 평화연구회.

외교통상부. 2007. ${ }^{\circledR} \mathrm{OECD}$ 개발원조위원회 회원국의 원조정책』. 서울: 외교 통상부

장현식, 아더 엠. 펠, 마이클 레어드. 2007. ${ }^{\circledR} \mathrm{OECD} / \mathrm{DAC}$ 회원국의 개발협력 관리 체계 비교』정책연구 2007-6-141. 서울: 한국국제협력단

전승훈, 유철, 김익기, 이주현. 2008. 개발원조에 대한 대국민 여론조사 및 정부의 국제개 발협력정책의 방향 연구』. 국제개발협력학회.

진영. 2009. 「대외원조기본법안」, 2009년 7월 10일 제안.

참여연대. 2008. 『2008 ODA 정책보고서: ODA 목적과 원조체계』.참여연대 정책자료 집.

최철영.2005.「대외원조기본법안의 비교법적 검토」 『민주법학』2005년 통권 28호. 


\section{2. 국외문헌}

Alexander George and Robert Keohane. 1980. “The concept of national interests: Uses and Limitations," Presidential Decisionmaking in Foreign Policy. Boulder: Westview.

Alexander Wendt. 2000. Social Theory of International Politics. New York: Cambridge University Press.

OECD. 2004. Managing Aid: Practices of DAC Member Countries. Paris: OECD.

OECD. 2008. Development Co-operation Report. Paris: OECD. 